\title{
ORIGINAL
}

\section{Properties of Cholesterol Oxidase Produced by Rhodococcus equi MIL $1037^{\dagger}$}

\author{
Mitsugi IIdA*, Yasuyuki Iwama, and Shigeru MineKI \\ Department of Applied Biological Science, Faculty of Science \\ and Technology, Science University of Tokyo \\ (Noda-shi, Chiba-ken, T278)
}

\begin{abstract}
Cholesterol oxidase produced by Rhodococcus equi MIL 1037 was purified from the supernatant solution of the culture broth by ammonium sulfate fractionation, DEAE- and CM-cellulose column chromatography, hydroxyapatite column chromatography and Sephadex G-75 gel filtration. The resulting enzyme was shown homogeneous by disc gel electrophoresis. The molecular weight of the enzyme was estimated as 48,000 by SDS-gel electrophoresis. The enzyme contained 453 amino acid residues including 40 moles of alanine and 16 moles of tryptophan. The enzyme was specific to $3 \beta$-hydroxysteroids and its relative activity (RA) was 37.5 for $\beta$-sitosterol, 25 for $5 \alpha$-cholestan- $3 \beta$-ol, 25 for pregnenolone and 0.1 for stigmasterol on the basis of 100 for cholesterol. The $\mathrm{Km}$ value for the oxidation of cholesterol was $0.33 \mathrm{mM}$. The enzyme was inhibited by $\mathrm{CuSO}_{4}, \mathrm{AgNO}_{3}$ and $\mathrm{HgCl}_{2}$, and partially inhibited by $p$-chloromercuribenzoic acid, but unaffected by metal chelating reagents.
\end{abstract}

\section{Introduction}

Cholesterol oxidases [EC 1.1.3.6] from microorganisms are useful clinically for the determination of cholesterol in serum. Their properties from Nocardia ${ }^{1,2)}$, Brevibacterium ${ }^{3)}$, Streptomyces $^{4), 5)}$, Schizophyllum ${ }^{6)}$, Corynebacterium ${ }^{7)}$, Streptoverticillium $^{8)}$ and Arthrobacter ${ }^{9)}$ have been studied by many investigators. On the other hand, these enzymes oxidize cholesterol at the first step in the microbial decomposition of $\mathrm{it}^{\mathrm{t}^{10)}}$. In the previous papers ${ }^{11,12)}$, we have isolated Rhodococcus equi MIL 1037 capable of degrading cholesterol and $\beta$-sitosterol (campesterol) selectively to 20-carboxy-pregnane derivatives in the presence of $\alpha, \alpha^{\prime}$-dipyridyl. These acids can be very useful intermediates for the production of corticosteroid hormones. Moreover, k-3, the mutant of MIL 1037, accumulated these acids without the chelating reagent. Therefore, it is significative to investigate the enzymes participating transformation of steroides in these strains.

In this paper, the purification and properties of cholesterol oxidase produced by $R$. equi MIL

$\uparrow$ Studies on Microbial Transformations (XXV)

* Corresponding author
1037 are descrived as a part of studies on the microbial transformation of steroids.

\section{Experimental}

\subsection{Microorganism}

$R$. equi MIL 1037 which was able to use kerosene or cholesterol as a sole source of carbon was isolated from soil. This strain was found to be capable of cleaving the side-chain of $\beta$-sitosterol ${ }^{11)}$ and to produce abundantly cholesterol oxidase in the culture broth.

\section{$2 \cdot 2$ Cultivation}

The cultivation of MIL 1037 for cholesterol oxidase production was carried out in a $500 \mathrm{~mL}$ Erlenmyer flask containing $100 \mathrm{~mL}$ of modified nutrient medium $(0.5 \%$ glucose, $0.5 \%$ beef extract, $1 \%$ corn steep liquor and $0.2 \% \mathrm{~K}_{2} \mathrm{HPO}_{4}$, $\mathrm{pH} 7.2$ ) at $27^{\circ} \mathrm{C}, 220 \mathrm{rpm}$.

\subsection{Assay of the enzyme activity}

Assay method 1: The oxidizing activity of cholesterol oxidase was assayed by estimating the initial rate of oxygen consumption at $30^{\circ} \mathrm{C}$ with a Clark oxygen electrode (Oxygraph 8, Central Kagaku Co. Ltd.). After the solution (total $1.0 \mathrm{~mL}$ ) containing $10 \mathrm{mM}$ of phosphate buffer $(\mathrm{pH} \mathrm{7.0)}$ and the enzyme was saturated with air, the reaction was initiated by the addi- 
tion of cholesterol $(1 \mu$ mole in $0.02 \mathrm{~mL}$ of ethanol). One unit of cholesterol oxidase was defined as the amount of the enzyme oxidizing 1 $\mu$ mole of cholesterol (corresponding the consumption of $1 \mu$ mole of oxygen) per min.

Assay method 2 : Cholest-4-en-3-one producing activity of the enzyme was assayed by the method of Stadtman ${ }^{13)}$ with modifications. After $0.9 \mathrm{~mL}$ of $10 \mathrm{mM}$ phosphate buffer $(\mathrm{pH} 7.0)$ was mixed with $0.1 \mathrm{~mL}$ of enzyme solution, $0.02 \mathrm{~mL}$ of cholesterol solution $(50 \mathrm{mM}$ in ethanol) was added and incubated at $30^{\circ} \mathrm{C}$ for $15 \mathrm{~min}$. At the end of the incubation, $4.0 \mathrm{~mL}$ of ethanol was added to the reaction mixture and the amount of cholest-4-en-3-one was determined by measuring absorbance at $240 \mathrm{~nm}$.

\subsection{Determination of protein concentration}

Concentrations of protein were measured by the method of Lowry et al. ${ }^{14)}$ using bovine serum albumin as a standard, and by the measurement of absorbance at $280 \mathrm{~nm}$.

\subsection{Electrophoresis}

Polyacrylamide gel disc electrophoresis was performed by the method of Davis ${ }^{15)}$. The molecular weight of the purified enzyme was estimated by SDS-polyacrylamide gel electrophoresis according to the method of Weber and Osborn ${ }^{16)}$

\subsection{Product analysis}

The reaction mixture was extracted with ethyl acetate and analyzed by GLC (Hitachi 663, $1.5 \%$ OV-17, $285^{\circ} \mathrm{C}$ ). Further purification was performed by column chromatography (Wakogel C-200) with $n$-hexane/ethyl acetate (25:1, vol/ $\mathrm{vol})$. IR and Ms spectra of the purified product were also measured in the same way as in the previous paper ${ }^{17)}$.

\subsection{Amino acid analysis}

Amino acid analysis was performed with a Hitachi amino acid analyzer, Model 835. The enzyme was hydrolyzed in $6 \mathrm{~N} \mathrm{HCl}$ in a sealed evacuated tube at $110^{\circ} \mathrm{C}$ for 24,48 and $72 \mathrm{~h}^{18)}$. Methionine and cysteine were determined according to the method of Moore ${ }^{19)}$. Tryptophan was measured after hydrolysis in $4 \mathrm{~N}$ methanesulfonic acid $^{20)}$.

\subsection{Materials}

Cholesterol and cholest-4-en-3-one were purchased from Wako Pure Chemical Industries Ltd. and Sigma Co., respectively. Other ster- oids used were obtained from Tokyo Chemical Industries Ltd. and Sigma Chemical Co. Other chemicals were of the highest purity commercially available.

\subsection{Purification of the enzyme}

All operations were carried out at $0 \sim 4^{\circ} \mathrm{C}$, unless otherwise specified. The enzyme activity was measured by "Assay method 1".

Step 1: Ammonium sulfate fractionation : From the culture filtrate $(10 \mathrm{~L})$, the precipitate with ammonium sulfate $(40 \sim 60 \%$ saturation $)$ was collected by centrifugation and dissolved in $400 \mathrm{~mL}$ of $10 \mathrm{mM}$ Tris- $\mathrm{HCl}(\mathrm{pH} 8.0)$ and dialyzed against the same buffer for $48 \mathrm{~h}(5 \mathrm{~L} \times 5$ times).

Step 2: DEAE-cellulose column chromatography : The dialyzed solution $(550 \mathrm{~mL})$ was applied to a DEAE-cellulose column $(2.6 \times 60 \mathrm{~cm})$ previously equilibrated with $10 \mathrm{mM}$ Tris $\mathrm{HCl}$ buffer, $\mathrm{pH}$ 8.0. The column was eluted with the same buffer at a flow rate of $60 \mathrm{~mL} / \mathrm{h}$. The active fractions were concentrated and dialyzed against $10 \mathrm{mM}$ sodium phosphate buffer $(\mathrm{pH}$ 7.0) for $48 \mathrm{~h}$.

Step 3 : CM-cellulose column chromatography : The dialyzed solution $(150 \mathrm{~mL})$ obtained from Step 2 was applied to a CM-cellulose column $(2.6 \times 60 \mathrm{~cm})$ previously equilibrated with

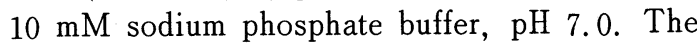
charged column was washed with the same buffer and eluted with $25 \mathrm{mM}$ of the same buffer. The active fractions were concentrated and dialyzed for $48 \mathrm{~h}$ against $10 \mathrm{mM}$ of the same buffer.

Step 4 : Hydroxyapatite column chromatography : The dialyzed solution was applied to a hydroxyapatite column $(5.0 \times 15 \mathrm{~cm})$ preequilibrated with $10 \mathrm{mM}$ sodium phosphate buffer, $\mathrm{pH}$ 7.0. The charged column was washed with $50 \mathrm{mM}$ of the same buffer and eluted with $100 \mathrm{mM}$ of the same buffer. The active fractions were concentrated and dialyzed for $48 \mathrm{~h}$ against $10 \mathrm{mM}$ of the same buffer.

Step 5 : Sephadex G-75 gel filtration: The dialyzed solution $(5 \mathrm{~mL})$ from Step 4 was applied to a Sephadex G-75 column $(2.6 \times 60 \mathrm{~cm})$ previously equilibrated with $10 \mathrm{mM}$ sodium phosphate buffer $(\mathrm{pH} 7.0)$. The column was eluted with the same buffer and then the active fractions were concentrated and dialyzed for $48 \mathrm{~h}$ 
Table-1 Summary of purification of cholesterol oxidase from R. equi MIL 1037.

\begin{tabular}{l|c|c|c|c}
\hline \multicolumn{1}{c|}{ Step } & Total protein $(\mathrm{mg})$ & Total activity (units) & Specific activity (units $/ \mathrm{mg})$ & Yield (\%) \\
\hline Culture supernatant & 27,000 & 3,750 & 0.14 & 100 \\
$\left(\mathrm{NH}_{4}\right)_{2} \mathrm{SO}_{4}$ ppt & 5,600 & 2,250 & 0.40 & 60.0 \\
$\mathrm{DEAE}-$ cellulose & 800 & 1,750 & 2.19 & 46.7 \\
$\mathrm{CM}$-cellulose & 320 & 1,350 & 4.22 & 36.0 \\
Hydroxyapatite & 75 & 850 & 11.3 & 22.6 \\
Sephadex G-75 & 22 & 470 & 21.4 & 12.5 \\
\hline
\end{tabular}

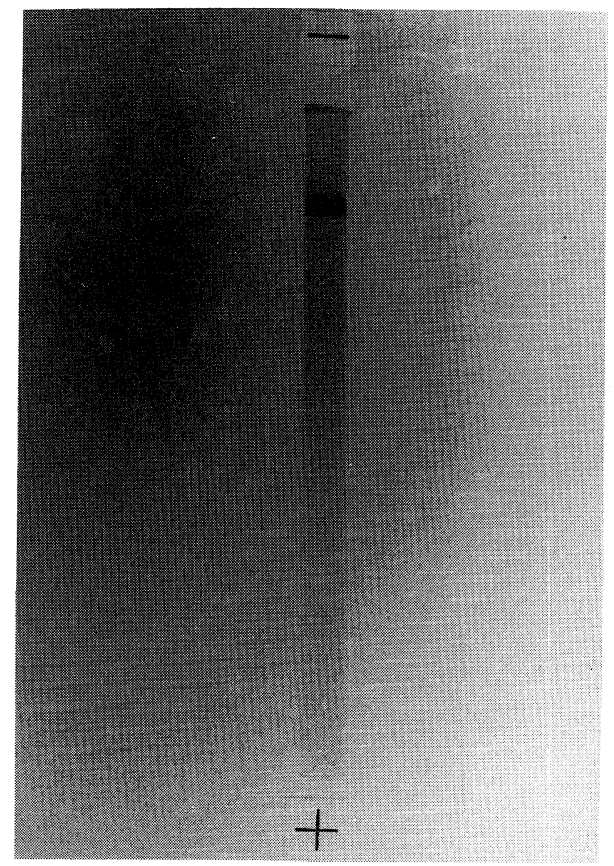

Disc electrophoresis was performed with 50 $\mu \mathrm{g}$ of enzyme at a constant current of $4 \mathrm{~mA}$ per gel for $2 \mathrm{~h}$. The gel was stained with Coomassie brilliant blue R-250 and destained in $10 \%$ acetic acid.

Fig. -1 Disc electrophoresis of purified cholesterol oxidase.

against the same buffer. After this process, the preparation of cholesterol oxidase gave a single band in disc electrophoresis on a polyacrylamide gel column (Fig.-1).

A summary of the purification procedures for the cholesterol oxidase is shown in Table-1. From the culture filtrate, this enzyme was purified 153 -fold and recovery of the activity was $12.5 \%$.

\section{Results and Discussion}

\subsection{Molecular weight}

The molecular weight of the enzyme was esti-

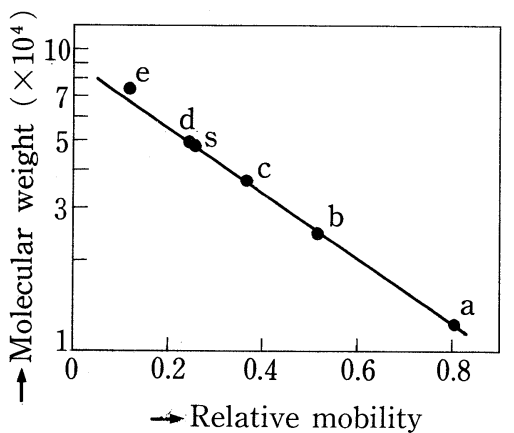

Relative mobility expresses the distance of migration relative to that of bromophenol blue. s, Cholesterol oxidase ; a, cytochrome c monomer (M.W., 12,300); b, dimer (M.W., 24,600) ; c, trimer (M.W., 36,900) ; d, tetramer (M.W., $49,200)$; e, hexamer (M.W., 73,800).

Fig. -2 Estimation of molecular weight of cholesterol oxidase by SDS-polyacrylamide gel electrophoresis.

mated from the $R_{f}$ value on SDS-polyacrylamide gel electrophoresis. As shown in Fig.-2, the molecular weight of this enzyme was found to be approximately 48,000 . This value is similar to that of Schizophyllum $(53,000)^{6)}$ but comparatively small than those of colesterol oxidases from other microbes $(56,000-61,000)^{2), 55,7) \sim 9)}$ mentioned above excepting Brevibacterium $(32,500)^{3}$.

\subsection{Optimum $\mathbf{p H}$ and $\mathbf{p H}$ stability}

As shown in Fig.-3, the enzyme had a very common optimum $\mathrm{pH}$ (7.5 for cholesterol) observed in other microbial cholesterol oxidases ( $\mathrm{pH}$ 7.0-7.5) excepting for Shizophyllum $(\mathrm{pH}$ $4-5)^{6)}$. The enzyme was stable over the $\mathrm{pH}$ range of 7.0-9.0 for $24 \mathrm{~h}$ at $4^{\circ} \mathrm{C}$, and was comparatively unstable in acidic $\mathrm{pH}$ than others $^{1,3), 7) \sim 9)}$. 


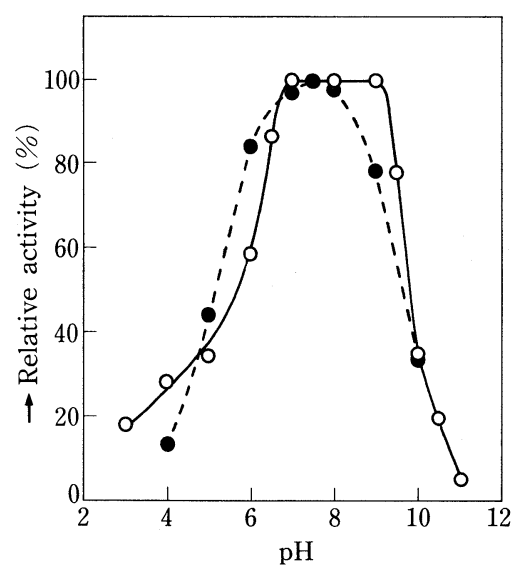

Citrate buffer, acetate buffer, phosphate buffer, borate buffer and carbonate buffer were used. Optimum $\mathrm{pH}$ : The enzyme activity was measured by "Assay method 2" with 0.21 unit of the enzyme except for using each of above buffers $(0.1 \mathrm{mM})$ instead of $10 \mathrm{mM}$ phosphate buffer. The reaction was carried out at indicated $\mathrm{pH}$ for $5 \mathrm{~min}$ at $30^{\circ} \mathrm{C}$. pH Stability : To the enzyme solution (0.1 mL, 1.1 unit), $0.4 \mathrm{~mL}$ of $50 \mathrm{mM}$ of each buffer was added and incubated at indicated $\mathrm{pH}$ for $24 \mathrm{~h}$ at $4^{\circ} \mathrm{C}$. After the incubation, $4.5 \mathrm{~mL}$ of $0.1 \mathrm{M}$ phosphate buffer $(\mathrm{pH} 7.0)$ was added and the activity was measured by "Assay method 1". Symbols

: O, optimum $\mathrm{pH} ; \mathrm{O}, \mathrm{pH}$ stability.

Fig. -3 Effect of $\mathrm{pH}$ on the enzyme activity of cholesterol oxidase.

\subsection{Optimum temperature and thermosta- bility}

The enzyme reaction was carried out at various temperatures at $\mathrm{pH} 7.0$ for $5 \mathrm{~min}$. As shown in Fig.-4, optimum temperature of the purified cholesterol oxidase was $45^{\circ} \mathrm{C}$. It was lower than the enzymes from Streptomycest) and Arthrobacter ${ }^{9}\left(50^{\circ} \mathrm{C}\right)$, but higher than Corynebacterium's $\left(40 \sim 42^{\circ} \mathrm{C}\right)^{7}$. The purified enzyme was stable at temperature below $35^{\circ} \mathrm{C}$ for $1 \mathrm{~h}$ at $\mathrm{pH}$ 7.0 but, while about $90 \%$ of the activity remained at $40^{\circ} \mathrm{C}, 30 \%$ at $50^{\circ} \mathrm{C}$, and the enzyme completely lost the activity at $60^{\circ} \mathrm{C}$. This enzyme was more labile against heat than the enzymes from Brevibacterium ${ }^{3)}$, Nocardia ${ }^{1)}$ and Corynebacterium $^{7}$ which maintain the activities more than $98 \%$ after the treatment at $50^{\circ} \mathrm{C}$.

\subsection{Effect of salts and other chemicals}

Effect of various salts and other chemical reagents on the enzyme activity is summarized in

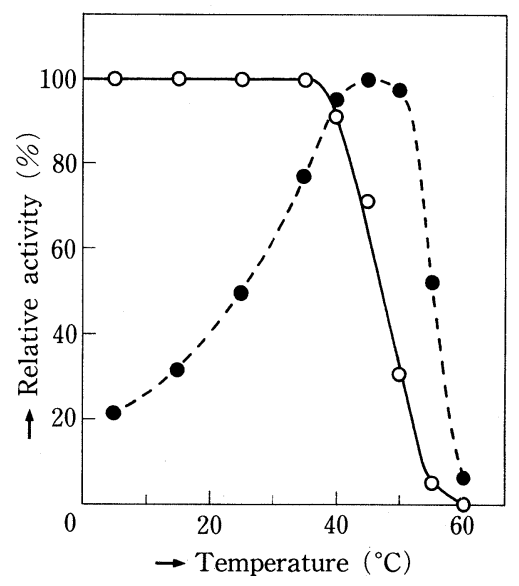

Optimum temperature : The enzyme activity was measurerd by "Assay method 2" except for the reaction temperature. The reaction was carried out at indicated temperature for $5 \mathrm{~min}$. Thermostability : The enzyme in $10 \mathrm{mM}$ phosphate buffer $(0.21$ unit/mL, $\mathrm{pH} \mathrm{7.0)} \mathrm{was} \mathrm{kept} \mathrm{at} \mathrm{the} \mathrm{indicated}$ temperature for $1 \mathrm{~h}$. Residual activity was measured by "Assay method 1". Symbols : , optimum temperature ; $\bigcirc$, thermostability.

Fig. -4 Effect of temperature on the enzyme activity of cholesterol oxidase.

Table-2 and 3. This enzyme was considerably inhibited by $\mathrm{CuSO}_{4}, \mathrm{AgNO}_{3}$ and $\mathrm{HgCl}_{2}$ at higher concentration than $1 \mathrm{mM}$. The enzyme activity reduced by the latter two salts was almost completely recovered by adding either glutathione or dithiothreitol. SH-group-inhibitor of $p$-chloromercuribenzoic acid ( $p$-CMB) partially inhibited the activity. This is in accord with the results in Brevibacterium ${ }^{3}$, Corynebacterium ${ }^{7}$ and Arthrobacter' enzymes, but is different from the results in Streptomycest) and Streptoverticillium ${ }^{8)}$ enzymes which are not inhibited by $p$-CMB. $p$ Chloromercuribenzenesulfonic acid and monoiodoacetic acid, however, failed to inhibit the enzyme activity. No metal chelating reagents such as EDTA, o-phenanthroline, $\alpha, \alpha^{\prime}$-dipyridyl, 8-hydroxyquinoline and KCN significantly inhibited the activity of the enzyme. Therefore, it is likely that no metal ions are associated with the action of the enzyme.

\subsection{Identification of the product}

The retention time $(9.5 \mathrm{~min})$ of the product coincided with that of cholest-4-ene-3-one in 
Table-2 Effect of salts on cholesterol oxidase.

\begin{tabular}{|c|c|c|c|}
\hline \multirow[t]{2}{*}{ Salts } & \multicolumn{3}{|c|}{$\frac{\text { Relative activity (\%) }}{\text { Concentration }}$} \\
\hline & $10 \mathrm{mM}$ & $1 \mathrm{mM}$ & $0.1 \mathrm{mM}$ \\
\hline $\mathrm{CaCl}_{2}$ & 61 & 98 & 108 \\
\hline $\mathrm{MgCl}_{2}$ & 98 & 100 & 112 \\
\hline $\mathrm{FeCl}_{3}$ & 22 & 95 & 100 \\
\hline $\mathrm{FeSO}_{4}$ & 15 & 71 & 97 \\
\hline $\mathrm{CuSO}_{4}$ & 6 & 14 & 84 \\
\hline $\mathrm{Na}_{2} \mathrm{MoO}_{4}$ & 17 & 97 & 100 \\
\hline $\mathrm{CoCl}_{2}$ & 38 & 82 & 101 \\
\hline $\mathrm{NiCl}_{2}$ & 79 & 93 & 104 \\
\hline $\mathrm{MnCl}_{2}$ & 22 & 84 & 84 \\
\hline $\mathrm{AgNO}_{3}$ & 0 & 5 & 52 \\
\hline + $10 \mathrm{mM}$ glutathione & 100 & - & - \\
\hline$+10 \mathrm{mM} \mathrm{DTT}^{*}$ & 94 & - & - \\
\hline $\mathrm{HgCl}_{2}$ & 0 & 10 & 56 \\
\hline + $10 \mathrm{mM}$ glutathione & 98 & - & - \\
\hline + $10 \mathrm{mM} \mathrm{DTT}^{*}$ & 96 & - & - \\
\hline
\end{tabular}

The mixture $(1.0 \mathrm{~mL}, 10 \mathrm{mM}$ phosphate buffer, $\mathrm{pH}$ 7.0) of salt and enzyme $(5 \mu \mathrm{g})$ was incubated at $30^{\circ} \mathrm{C}$ for $15 \mathrm{~min}$, and then the residual activity was measured by "Assay method 2". The absorbance of control at $240 \mathrm{~nm}(0.294)$ was basis (100\%).

* Dithiothreitol.

Table-3 Effect of chemical reagents on cholesterol oxidase.

\begin{tabular}{l|c|c}
\hline \multirow{2}{*}{\multicolumn{1}{c|}{ Chemicals }} & \multicolumn{2}{c}{ Relative activity (\%) } \\
\cline { 2 - 3 } & \multicolumn{2}{|c}{ Concentration } \\
\hline$p-$ CMB $^{*}$ & - & $1 \mathrm{mM}$ \\
$p$-CMS & 72 \\
Monoiodoacetic acid & - & 103 \\
EDTA & - & 108 \\
o-Phenanthroline & 100 & - \\
$\alpha, \alpha^{\prime}-$ Dipyridyl & 100 & - \\
8-Quinolinol & 100 & - \\
KCN & 100 & - \\
\hline
\end{tabular}

The mixture $(1.0 \mathrm{~mL}, 10 \mathrm{mM}$ phosphate buffer, $\mathrm{pH} 7.0)$ of chemical reagent and enzyme $(5 \mu \mathrm{g})$ was incubated at $30^{\circ} \mathrm{C}$ for $15 \mathrm{~min}$, and then the residual activity was measured by "Assay method 2". The absorbance of control at $240 \mathrm{~nm}(0.294)$ was basis (100\%).

${ }^{*} p$-Chloromercuribenzoic acid.

${ }^{* *} p$-Chloromercuribenzenesulfonic acid.
GLC analysis. Ms of the purified product revealed an ion peak of $m / z 384$ in agreement with the formula $\mathrm{C}_{27} \mathrm{H}_{44} \mathrm{O}$. IR spectrum of it completely agreed with that of cholest-4-ene-3-one. From these results, the product of the reaction was confirmed as cholest-4-ene-3-one.

\section{$3.6 \mathrm{Km}$ value}

The reaction was found to follow the normal Michaelis-Menten kinetics, and the LineweaverBurk plot indicated the $K m$ value of the enzyme toward cholesterol to be $3.3 \times 10^{-4} \mathrm{M}$ (Fig. -5 ). Dissolved oxygen was not rate limiting factor in this reaction, because the plot was linear in the region of $0.1 \sim 0.4 \mathrm{mM}$ of cholesterol. This $\mathrm{Km}$ value was identical with that of Schizophyllum's enzyme $^{6)}$ and lower than that of either Streptomyces's or Streptoverticillium's enzyme $\{(4.0-6.7) \times$ $\left.10^{-4} \mathrm{M}\right)^{4), 8}$, but the enzymes from Nocardia ${ }^{1,2)}$, Corynebacterium $^{7}$ and Arthrobacter ${ }^{9}$ was reported to have remarkably lower $K m$ values (1.97-30.8 $\mu \mathrm{M})$ than Rhodococcus's enzyme purified in this study.

\subsection{Amino acids analysis}

The amino acid composition of the purified enzyme, expressed as residues per 48,000 molecular weight, is shown in Table-4. The number of residues per molecule of protein was 453 including 40 moles of alanine and 16 moles of tryptophan. Although this enzyme has higher content of threonine than the enzymes from other microbes ${ }^{3,6), 7)}$, it has a common amino acids composition, while that from Brevibac-

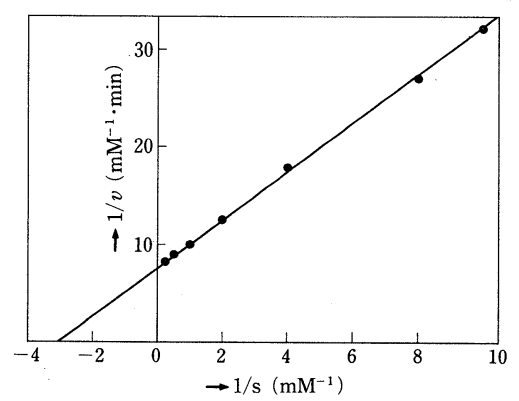

To $1.0 \mathrm{~mL}$ of the enzyme solution $(0.11$ unit, $10 \mathrm{mM}$ phosphate buffer, $\mathrm{pH} \mathrm{7.0)}$, $0.02 \mathrm{~mL}$ of cholesterol/ethanol solution was added to give the final concentration as indicated. The enzyme activity was measured by "Assay method 1".

Fig. -5 Lineweaver-Burk plot for cholesterol oxidase. 
Table-4 Amino acid composition of cholesterol oxidase.

\begin{tabular}{|c|c|c|}
\hline Amino acid & $\mathrm{mol} \%$ & $\begin{array}{l}\text { Integral } \\
\text { number of } \\
\text { residues }\end{array}$ \\
\hline Aspartic acid & 10.33 & 47 \\
\hline Threonine a) & 9.34 & 42 \\
\hline Serine ${ }^{\text {a) }}$ & 7.67 & 35 \\
\hline Glutamic acid & 6.77 & 31 \\
\hline Glycine & 12.87 & 58 \\
\hline Alanine & 8.89 & 40 \\
\hline Valine $^{b)}$ & 7.84 & 35 \\
\hline Isoleucine b) & 4.63 & 21 \\
\hline Leucine $^{\text {b) }}$ & 5.85 & 26 \\
\hline Tyrosine & 2.46 & 11 \\
\hline Phenylalanine & 3.47 & 16 \\
\hline Lysine & 4.99 & 23 \\
\hline Histidine & 0.94 & 4 \\
\hline Arginine & 3.25 & 15 \\
\hline Proline & 4.65 & 21 \\
\hline Tryptophanc) & 3.48 & 16 \\
\hline Half-cystine ${ }^{\mathrm{d})}$ & 1.27 & 6 \\
\hline Methionine ${ }^{e)}$ & 1.33 & 6 \\
\hline Total & 100.03 & 453 \\
\hline
\end{tabular}

The number of residues per molecule of protein was calculated on the basis of the molecular weight of 48,000 .

a) Extrapolated to zero time of hydrolysis.

b) Adopted from the value of $72 \mathrm{~h}$ hydrolysis.

c) Hydrolysis in $4 \mathrm{~N}$ methanesulfonic acid ${ }^{20)}$.

d) Determined as cysteic acid ${ }^{19)}$.

e) Determined as methionine sulfone ${ }^{19)}$.

terium $^{3}$ is unusual in that it contains neither alanine nor tryptophan residue and has a high content of proline.

\subsection{Substrate specificity}

The relative oxidation rate of the enzyme for various 3-hydroxysteroids were measured. As shown in Table-5, the enzyme was specific for $3 \beta-\mathrm{OH}$ steroids and did not attack $3 \alpha-\mathrm{OH}$ ones. Of the steroids tested, cholesterol was oxidized most efficiently. The enzyme was more active for steroids having double bond at the 5 position [cholesterol and dehydroepiandrosteron (DHEA)] than $5 \alpha$-steroids $(5 \alpha$-cholestan- $3 \beta$-ol and epiandrosterone), and inactive for $5 \beta$-steroids (A/ $\mathrm{B}$ cis : $5 \beta$-cholestan- $3 \beta$-ol and $5 \beta$-androstan$3 \beta$-ol-17-one) in either $C_{27}$ or $C_{19}$ steroids. In
Table-5 Relative rates of oxidation of various hydroxy steroids by cholesterol oxidase.

\begin{tabular}{l|c}
\hline \multicolumn{1}{c|}{ Substrate } & $\begin{array}{c}\text { Relative rate } \\
(\%)\end{array}$ \\
\hline $3 \beta$-OH type & 100 \\
Cholesterol & 37.5 \\
$\beta$-Sitosterol & 25.0 \\
$5 \alpha$-Cholestan-3 $\beta$-ol & 25.0 \\
Pregnenolone & 18.8 \\
Dehydroepiandrosterone & 6.3 \\
Epiandrosterone & 0.1 \\
Stigmasterol & 0.0 \\
Diosgenin & 0.0 \\
Ergosterol & 0.0 \\
$5 \beta$-Cholestan-3 $\beta$-ol & 0.0 \\
$5 \beta$-Androstan-3 $\beta$-ol-17-one & \\
$3 \alpha$-OH type & 0.0 \\
$5 \beta$-Cholestan-3 $\alpha$-ol & 0.0 \\
$5 \alpha$-Cholestane-3 $\alpha$-ol & 0.0 \\
$5 \beta$-Androstan-3 $\alpha$-ol-17-one & 0.0 \\
Lithocholic acid & 0.0 \\
Cholic acid & \\
\hline
\end{tabular}

The enzyme activity was measured by "Assay method 1" except for using the indicated steroid instead of cholesterol.

$\Delta^{5}$ steroids, the enzyme activity for steroids having branch ( $\beta$-sitosterol) and double bond (stigmasterol) in the side chain at the 17 position and for steroids having comparatively short or no side chain (pregnenolone and DHEA) drastically reduced. Moreover, the activity for ergosterol and diosgenin could not be recognized. From these results, the substrate specificity of the enzyme is similar to that of Brevibacterium $^{3}$ but remarkably different from those of Streptomyces ${ }^{5)}$ and Streptoverticillium ${ }^{8}$ whose enzymes can oxdize $5 \alpha$-cholestan- $3 \beta$-ol well [relative activity (RA) : $101 \%$ and $96 \%$, respectively]. The enzymes from Corynebacterium $^{7}$ and Arthrobacter ${ }^{9}$ can oxidize ergosterol and the latter enzyme has activity even for diosgenin. The enzyme of Nocardia erythropolis ${ }^{2}$ has high RA ( $82 \%)$ for pregnenolone. On the other hand, a double bond in the 5 or 4 position of the steroid is essential for the enzyme from Nocardia sp. ${ }^{1}{ }^{1}$, which cannot oxidize $5 \alpha$ cholestan-3 $\beta$-ol. Cholesterol oxidase of Rhodococcus, therefore, is found to have a comparatively high specificity for cholesterol than the 
enzymes from other microbes except that the enzyme of Nocardia $\mathrm{sp}^{1)}$. is inactive for the $5 \alpha$ -steroids (the enzyme of Rhodococcus purified in this study showed RA of $25 \%$ even for $5 \alpha$ -cholestan- $3 \beta$-ol as shown in Table-5).

Cholesterol oxidase is thought to react with the substrate at the first step in the microbial decomposition of steroids ${ }^{10}$, and we reported that $\beta$-sitosterol was better substrate than cholesterol to produce 20-carboxy-pregna-1,4-dien-3one (BNC) by Rhodococcus equi MIL 103711,21). Namely, maximal yields $(\%)$ of BNC from $\beta$ -sitosterol, cholesterol and $5 \alpha$-cholestan- $3 \beta$-ol were 56,48 and 27 , respectively, while cholesterol oxidase of this strain was not so active for $\beta$-sitosterol (RA : $37.5 \%$ ). Consequently, the oxidation of $\beta$-sitosterol by cholesterol oxidase of this strain did not directly participate in the productivity of BNC.

\section{Acknowledgement}

We thank to Mr. M. Yoshihama, Snow Brand Milk Co. Ltd., for the animo acid analysis.

(Received Jun. 19, 1989)

\section{References}

1) W. Richmond, Clin. Chem., 19, 1350 (1973).

2) C. J.W. Brooks and A. G. Smith, J. Chromatogr., 112, 499 (1975).

3) T. Uwajima, H. Yagi, and O. Terada, Agric. Biol. Chem., 38, 1149 (1974).

4) H. Tomioka, M. Kagawa, and S. Nakamura, J. Biochem., 79, 903 (1976).

5) T. Kamei, Y. Takiguchi, H. Suzuki, M. Matsuzaki, and S. Nakamura, Chem. Pharm. Bull., 26, 2799 (1978).

6) M. Fukuyama and Y. Miyake, J. Biochem., 85, 1183 (1979).

7) Y. Shirokane, K. Nakamura, and K. Mizusawa, J. Ferment. Technol., 55, 337 (1977).

8) Y. Inouye, K. Taguchi, A. Fujii, K. Ishimaru, S. Nakamura, and R. Nomi, Chem. Pharm. Bull., 30, 951 (1982).

9) W.H. Liu, M.H. Meng, and K.S. Chen, Agric. Biol. Chem., 52, 413 (1988).

10) K. Arima, M. Nagasawa, M. Bae, and G. Tamura, Agric. Biol. Chem., 33, 1636 (1969).

11) M. Iida, T. Murohisa, A. Yoneyama, and H.
Iizuka, J. Ferment. Technol., 63, 559 (1985).

12) M. Iida, K. Tsuyuki, S. Kitazawa, and H. Iizuka, J. Ferment. Technol., 65, 525 (1987).

13) T. C. Stadtman, in "Methods in Enzymology," Vol. 3, ed. by S.P. Colowick and N. O. Kaplan, Academic Press, New York (1957) p. 392 .

14) O.H. Lowry, N.T. Rosebrough, A.L. Farr, and R. J. Randall, J. Biol. Chem., 193, 265 (1951).

15) B. J. Davis, Ann. Nerw York Acad. Sci., 121, 404 (1964).

16) K. Weber and M. Osborn, J. Biol. Chem., 244, 4406 (1969).

17) M. Iida, A. Mikami, K. Yamakawa, and K. Nishitani, J. Ferment. Technol., 66, 51 (1988).

18) S. Moore and W.H. Stein, in "Methods in Enzymology," Vol.6, ed. by S.P. Colowick and N. O. Kaplan, Academic Press, New York (1963) p. 819.

19) S. Moore, J. Biol. Chem., 238, 235 (1963).

20) R. J. Simpson, M. R. Neuberger, and T.Y. Liu, J. Biol. Chem., 251, 1936 (1976).

21) M. Iida, K. Ueda, K. Tsuyuki, and H. Iizuka, Proc. Annu. Meet. Agric. Chem. Soc. Jpn., p. 56 (1985).

\section{Rhodococcus equi MIL 1037 の生産する \\ コレステロールオキシダーゼの性質}

飯田 貢, 岩間尉至, 峯木 茂 東京理科大学理工学部応用生物科学科 （テ 278 野田市山崎 2641）

Rhodococcus equi MIL 1037 の生産するコレステロー ルオキシダーゼをその培養上清から硫安分画, DEAEセルロース，CM-セルロース，ヒドロキシアパタイト， さらに，セファデックス G-75 カラムによって, ディス ク電気泳動で単一バンドを示すまでに分離精製した。本 酵素はSDS-ゲル電気泳動で分子量 48,000 と推定され, Ala 40 残基，Trp 16 残基を含む 453 個のアミノ酸残基 よりなっていた。また，本酵素は $3 \beta$-ヒドロキシステ ロイドに特異的で, コレステロールを 100 とした時の比 活性は， $\beta$-シトステロール 37.5，5 $\alpha$-コレスタン- $3 \beta$ オール 25，スティグマステロール0.1であり，コレス テロールに対する $K m$ 值は $0.33 \mathrm{mM}$ であった。さらに, 本醅素は $\mathrm{CuSO}_{4}, \mathrm{AgNO}_{3}, \mathrm{HgCl}_{2}$ によって完全に阻害 され，p-クロロ安息香酸水銀（II）では部分的な阻害を 受けたが，種々のキレート剤では阻害されなかった。 